\title{
POST-FRACTURING TREATMENTS DESIGN TO REDRESS THE DAMAGE CAUSED BY FRACTURING FLUID POLYMERS
}

\section{DISEÑO DE TRATAMIENTOS POST-FRACTURAMIENTO PARA REMEDIAR EL DAÑO CAUSADO POR FLUIDOS POLIMÉRICOS DE FRACTURA}

Fabián-Alfredo Carrascal-Delgado ${ }^{1 *}$, Zarith del Pilar Pachón-Contreras ${ }^{2}$ and Daniel-Ricardo Molina-Velasco ${ }^{1}$

\author{
'Universidad Industrial de Santander, Bucaramanga, Santander, Colombia \\ Ecopetrol S.A. - Instituto Colombiano del Petróleo (ICP), A.A. 4185, Bucaramanga, Santander, Colombia \\ e-mail: fabian.carrascal@correo.vis.edu.co
}

(Received: Apr. 05, 2014; Accepted: Oct. 10, 2014)

\begin{abstract}
even chemical products with different chemical properties were evaluated as post-fracturing treatments to remove the polymer retained in the pore system of the fracture and adjacent rock after hydraulic fracturing. $\checkmark$ Three of those chemical products were used for the first time to degrade the polymer in fracturing fluids. All laboratory tests were conducted under the Unit K-1 Chichimene oil-field conditions - located in Eastern Colombia, and operated by Ecopetrol S.A.
\end{abstract}

Fluid-fluid and fluid-rock compatibility tests were performed. In order to evaluate the capacity of the post-fracturing treatments to degrade the polymer in the fracturing fluid, a new methodology for polymer quantification was implemented. The chemical and thermal stability of the post-fracturing treatments was assessed trough coreflooding experiments. Finally, the evaluations of the effectiveness of the post-fracturing treatments were performed and assessed with coreflooding experiments using fractured rocks as porous media.

The coreflooding results showed that the post-fracturing treatments evaluated promoted the recovery of about $40 \%$ of the total polymer retained in the porous system, and improved the retained permeability in values between 50 and 180\%. The best obtained results came from the first-time usage of chemical products as post-fracturing treatments.

Keywords: Polymeric breakdown, Polymeric quantification, Porous media, Coreflooding, Permeability.

How to cite: Carrascal-Delgado, F. A., Pachón-Contreras, Z. \& Molina-Velasco, D. R. (2014). Post-fracturing treatments design to redress the damage caused by fracturing fluid polymers. CT\&F - Ciencia, Tecnología y Futuro, 5(5), 23-37.

${ }^{*}$ To whom correspondence should be addressed 


\section{RESUMEN}

O iete productos químicos, de diferente naturaleza química, fueron evaluados como tratamientos postfracturamiento hidráulico para remover el polímero retenido en la zona fracturada. Entre los productos evaluados se destacan tres productos usados por primera vez como componentes principales de tratamientos post-fracturamiento hidráulico. Las pruebas fueron realizadas a condiciones de los pozos productores del campo Chichimene, formación K-1, operados por Ecopetrol S.A., ubicados en los Llanos Orientales Colombianos.

Las pruebas realizadas incluyeron compatibilidad con los fluidos y las rocas de la formación, la aplicación de una nueva metodología para cuantificar de forma directa la degradación del polímero del fluido de fractura y la evaluación de la estabilidad térmica de los componentes principales de los tratamientos, entre otras. Finalmente, se realizaron pruebas de desplazamiento de los tratamientos post-fracturamiento a través de medios porosos que simulaban rocas fracturadas para determinar su efectividad en la remoción del polímero retenido.

Los resultados obtenidos muestran que la aplicación de los tratamientos post-fracturamiento promovieron la recuperación de aproximadamente un $40 \%$ del polímero total retenido en el sistema poroso, según su aplicación. Además, los valores de permeabilidad retenida mejoraron entre un 50 y 180\%; obteniéndose los mejores resultados empleando los productos químicos usados por primera vez como tratamientos postfracturamiento.

Palabras clave: Degradación polimérica, Cuantificación polimérica, Medio poroso, Desplazamiento de fluidos, Permeabilidad.

\section{RESUMO}

Cete produtos químicos, de diferente natureza química, foram avaliados como tratamentos pós-fratura hidráulica para remover o polímero retido na zona fraturada. Entre os produtos avaliados destacamse três produtos usados por primeira vez como componentes principais de tratamentos pós-fratura hidráulica. As provas foram realizadas em condições idênticas as dos poços produtores do campo Chichimene, formação K-1, operados por Ecopetrol S.A., localizados nas Planícies Orientais Colombianas.

As provas realizadas incluíram compatibilidade com os fluídos e com as rochas da formação, a aplicação de uma nova metodologia para quantificar de forma direta a degradação do polímero do fluído de fratura e a avaliação da estabilidade térmica dos componentes principais dos tratamentos, entre outras. Finalmente, foram realizadas provas de deslocamento dos tratamentos pós-fratura através de meios porosos que simulavam rochas fraturadas para determinar sua efetividade na remoção do polímero retido.

Os resultados obtidos mostram que a aplicação dos tratamentos pós-fratura promoveu a recuperação de aproximadamente $40 \%$ do polímero total retido no sistema poroso, segundo sua aplicação. Além disso, os valores de permeabilidade retida melhoraram entre 50 e 180\%; obtendo-se os melhores resultados empregando os produtos químicos usados por primeira vez como tratamentos pós-fratura.

Palavras-chave: Degradação polimérica, Quantificação polimérica, Meio poroso, Deslocamento de fluídos, Permeabilidade. 


\section{INTRODUCTION}

Hydraulic fracturing is one of the most commonly used stimulation techniques to accelerate and increase the production in oil and gas wells. However, hydraulic fracturing does not always produce the expected results, with polymeric residue retention in porous media (Wang, Holditch \& McVay, 2012) as the main cause for the variance in results. In addition, it has been calculated that the polymeric surface recovery is less than $50 \%$ of the total injected fluid during fracturing (Asadi \& Woodroof, 2006).

This paper presents the results of different chemical products as post-fracturing (post-frac) treatments for degrading the polymer retained in the pore system of the fracture and adjacent rock after hydraulic fracturing. Post-frac treatment application is an attractive option that has been used for several years to restore the polymeric damage in the fractured area with satisfactory results (Brannon \& Tjon-Joe-Pin, 1995; DeVine, Tjon-Joe-Pin \& Rickards, 1999) and has recently been implemented by Ecopetrol S.A.

These post-frac treatments were tested and evaluated in the laboratory under Unit K1-Chichimene oil-field conditions. Table 1 summarizes the chemical products, and concentrations used, where three of the chemical products where of first-time usage and the remaining four commercial breakers.
Additionally, the fracture fluid designed for Chichimene field was used in the present work. Table 2 shows the fracture fluid formulation.

Table 2. Fracture fluid designed for Chichimene field.

\begin{tabular}{cc|}
\hline Chemical Composition & Concentration (\%v/v) \\
Clay stabilizer & 0.20 \\
\hline Biocide & 0.02 \\
\hline Polymer (Guar gum) & $0.40 \% \mathrm{w} / \mathrm{v}$ \\
\hline Surfactant & 0.10 \\
\hline Gel stabilizer & 0.30 \\
\hline Buffer & 0.38 \\
\hline Crosslinker 1 & 0.10 \\
\hline Crosslinker 2 & 0.16 \\
\hline Breaker 1 (Oxidant) & 1.20 \\
\hline Breaker 2 (Oxidant) & 0.23 \\
\hline
\end{tabular}

At the outset, fluid-fluid and fluid-rock compatibility tests (including chemical interaction between formation sands and post-frac treatments) were performed, as well as different polymer degrading tests under static and dynamic conditions, and the assessment of coreflooding experiments.

In order to quantify the polymer degraded by the postfrac treatments under evaluation, the dinitrosalicylic acid (DNS) method was proposed as a fast and simple

Table 1. Chemical products tested as post-frac treatments.

\begin{tabular}{|c|c|c|c|}
\hline Breaker & Concentration $(\% \mathrm{v} / \mathrm{v})$ & \multicolumn{2}{|c|}{ Breaker Features } \\
\hline Ammonium persulfate & $1.2 \% \mathrm{w} / \mathrm{v}$ & Oxidant & Traditional \\
\hline Sodium perborate & $1.2 \% \mathrm{w} / \mathrm{v}$ & Oxidant & Traditional \\
\hline Sodium hypochlorite & 2.0 & Oxidant & Traditional \\
\hline Hydrochloric acid & 3.5 & Inorganic acid & Traditional \\
\hline Enzymatic treatment & 5.0 & Enzyme & Novel \\
\hline Organic treatment I & 7.0 & Organic acid & Novel \\
\hline Organic treatment II & 0.25 & Organic acid & Novel \\
\hline
\end{tabular}


method-compared to other methods and techniques such as anionic exchange chromatography (Hoeman, Klasner \& Karcher, 2011) or molecular ultrafiltration techniques (Brannon \& Joe, 1996)-. Yet, this method has not been implemented in the oil industry.

The DNS method is based on the endothermic reduction of the DNS (yellow color), by reducing sugars to produce the 3-amino-5-dinitrosalicylicacid (red brown color) with maximum absorption at a wavelength of $540 \mathrm{~nm}$ (Miller, 1959). Moreover, the DNS method is specific for quantifying reduced sugars (such as guar gum and their derivatives) and is a direct method for measuring polymer degradation of waterbased fracturing fluids.

Due to its high viscosity, water solubility, tolerance to water chemistry and low cost, guar gum is the most widely used polymer of the water-based fracturing fluids (Wientjes et al., 2001). In addition, guar gum is a natural polysaccharide composed of a backbone of manopyranoses with $\beta$ - $(1 \rightarrow 4)$ links, with only a reducing end per molecule, and partially replaced by a galactose unit linked via $\alpha-(1 \rightarrow 6)$ (Duxenneuner, Fischer, Windhab \& Cooper-White, 2008), being the ratio of mannose-galactose 1,5:2 (Wientjes, Duits, Jongschaap \& Mellema, 2000). When the polymers used in the fracturing fluids are degraded, smaller polymeric fragments are obtained. These fragments, although of lower molecular size, maintain the chemical properties of the starting polymer; and hence its ability to reduce the DNS.

The data obtained for the DNS method calibration with glucose standards were fitted using least squares method (see Figure 1), obtaining a $\mathrm{R}^{2}$ correlation coefficient between absorbance and glucose concentration equal to 0.9988 and the relation between the absorbance and glucose concentration given by Equation 1:

Absorbance $=0.0016^{*}$ Glucose Concentration - 0.0553 (1)

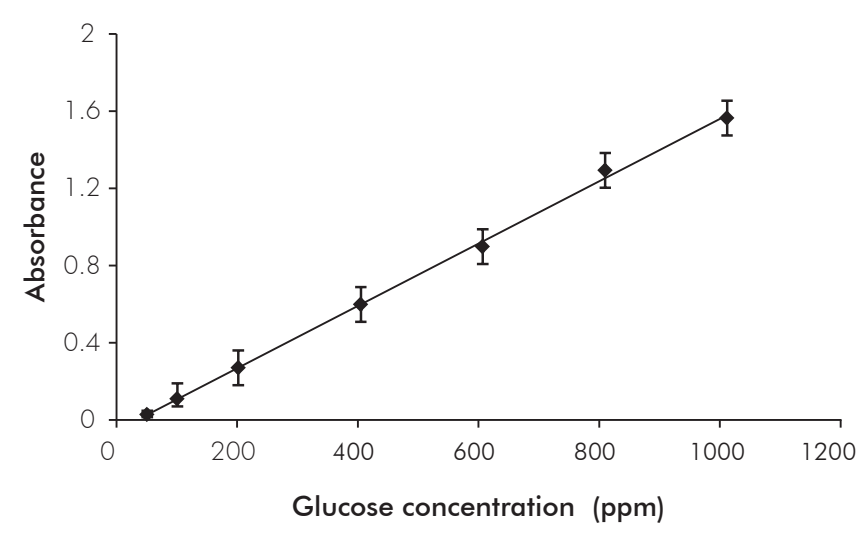

Figure 1. DNS calibration curve $\left(\lambda_{\max }=540 \mathrm{~nm}\right)$ using glucose standards.

\section{EXPERIMENTAL}

Figure 2 shows the general outline of the methodology used in the present work, in which new issues related to polymer degraded are considered.

Post-frac treatments were prepared using brine of potassium chloride $(\mathrm{KCl}) 1 \% \mathrm{w} / \mathrm{v}$ as base fluid, in distilled water. All tests were performed at the average temperature of the formation of interest $\left(110^{\circ} \mathrm{C}\right)$ in airtight glass jars.

\section{Post-Frac Treatments Compatibility with the Chichimene Oil, Unit K-1}

Using the API RP 42 as reference, phase separation and emulsion formations between oil from Chichimene-26 well ( $\mathrm{CH}-26$, Unit $\mathrm{K}-1)$, and post-frac treatments (50/50 and 20/80) were assessed qualitatively. The post-frac treatments were evaluated in three different conditions: 1) fresh treatments; 2) after their reaction with $0.3 \% \mathrm{w} / \mathrm{v}$ polymeric solution; 3 ) treatments dosed with $2000 \mathrm{ppm}$ iron $\left(\mathrm{Fe}^{+2}\right)$ in solution. Also, a commercial surfactant currently used in Chichimene field operations, was used to improve phase separation. Its concentration was optimized experimentally.

\section{Post-Frac Treatments Compatibility with Formation Rocks}

Crushed rocks samples from Unit K-1 obtained from cores of the wells Libertad Norte-1, and Apiay-11 


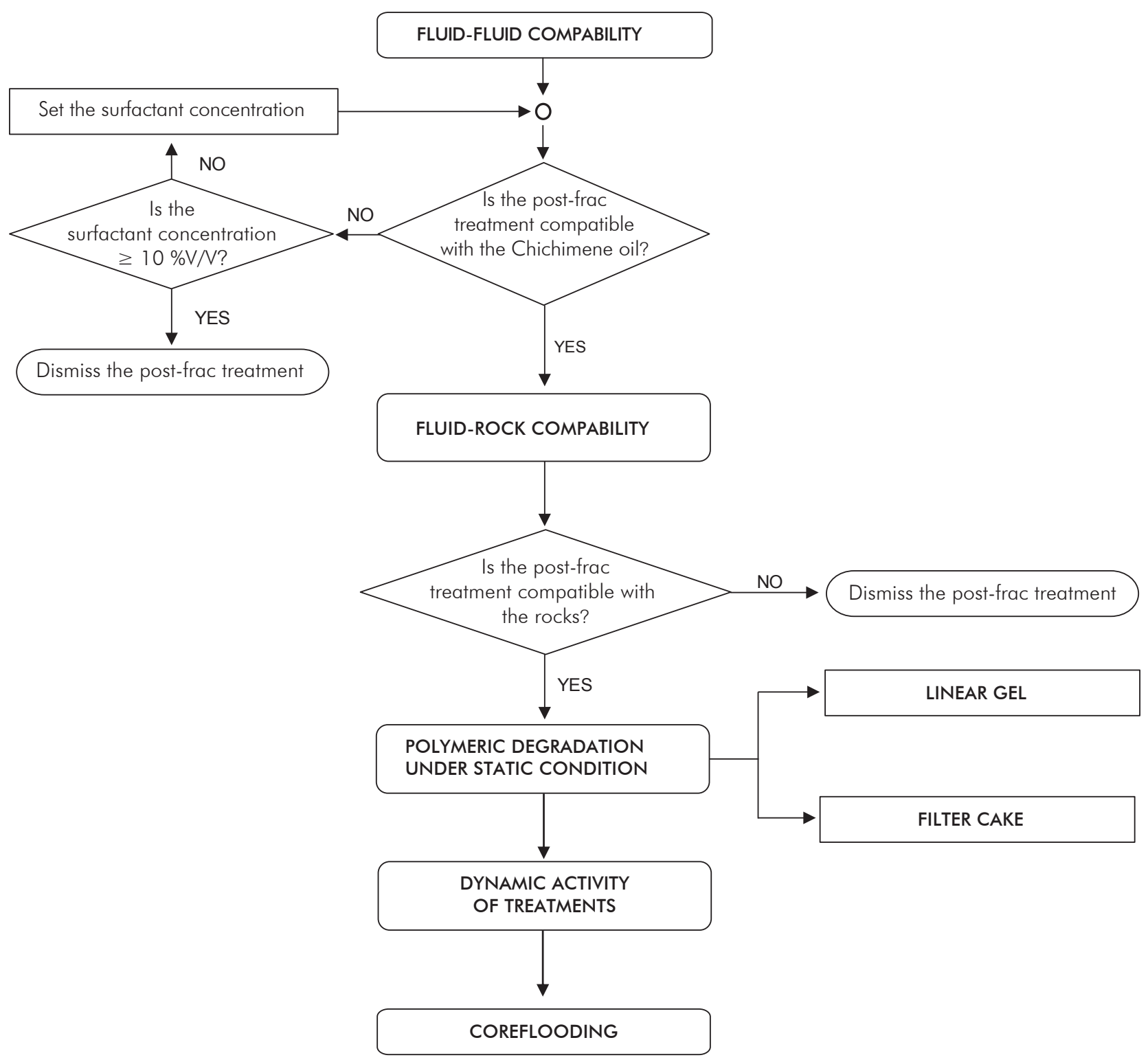

Figure 2. Methodology used for post fracturing treatments evaluation.

(depths 3337, and $3216 \mathrm{~m}$ respectively) were used. The tests were conducted based on API RP 58-1995. With the following qualification criteria:

- High concentrations of ions in the solution $\left(\mathrm{Na}^{+}, \mathrm{K}^{+}\right.$, $\mathrm{Ca}^{+2}, \mathrm{Mg}^{+2}, \mathrm{Fe}^{+2}, \mathrm{Al}^{+3}$, and $\mathrm{SiO}_{2}$ ) indicate high degree of reactivity of treatments with minerals presented in the rock samples.

- The maximum solubility of the rocks in post-frac treatments should not exceed $1 \%$. Values greater than this indicate the possibility of damage in the reservoir by fines generation.

\section{Polymer Degraded in the Fracturing Fluid}

Tests were performed using linear gel suspensions and filter cake. The linear gel was prepared using guar gum -the most common polymer used in water- based fracturing fluid-in $\mathrm{KCl} 1 \% \mathrm{w} / \mathrm{v}$ brine. The filter cake was obtained from the filtration of cross-linked fracturing fluid through a ceramic disc.

Polymer degradation was measured according to the DNS method (Miller, 1959). The calibration method was performed using standard anhydrous glucose solutions between 50 and $1000 \mathrm{ppm}$. $1 \mathrm{~mL}$ aliquots of each of the solutions were mixed with $1 \mathrm{~mL}$ of DNS to react 
at $100^{\circ} \mathrm{C}$ for 10 minutes. Subsequently, the samples were cooled in ice water to stop the reaction. Finally, absorbance was measured at the maximum absorption length: $540 \mathrm{~nm}$ (Carrascal, Pachón \& Molina, 2013).

\section{Linear Gel}

Glass reactors were prepared containing $75 \mathrm{~mL}$ suspensions of $0.4 \% \mathrm{w} / \mathrm{v}$ polymer in $\mathrm{KCl} 1 \% \mathrm{w} / \mathrm{v}$ brine. The post-frac treatments were dosed adjusting the concentrations to test. Afterward, volume was completed up to $100 \mathrm{~mL}$ using distilled water. The reactors were set up at $110^{\circ} \mathrm{C}$ for a reaction time of 23 hours. Aliquots were taken at different time intervals and polymer degradation was measured using the DNS method.

\section{Filter Cake}

The cake was generated in a Permeability Plugging Apparatus (PPA) filter press, by flowing fracturing fluid containing $0.4 \% \mathrm{w} / \mathrm{v}$ of polymer through Fann ceramic filters: $0.25 \mathrm{pm}^{2}$ air permeability, $6.35 \mathrm{~cm}$ diameter and $6.35 \mathrm{~mm}$ thick.

The ceramic disc was placed in the HTHP (High Temperature High Pressure) cell, and filled with $350 \mathrm{~mL}$ of fracturing fluid. The outlet valve of the equipment was kept in the open position while the nitrogen valve was adjusted to $0.69 \mathrm{MPa}$ to cool the filtrate. At that point, the cell was heated to $110^{\circ} \mathrm{C}$ and pressurized to maintain the differential pressure between 1.38 and 0.69 $\mathrm{MPa}$. The fracture fluid was filtered until $300 \mathrm{~mL}$ of filtered fluid was collected. Lastly, the equipment was allowed to cool to room temperature and pressure was released slowly, plus the ceramic filter was removed from the cell. There sulting cake was placed in capped glass reactors. Subsequently, $20 \mathrm{~mL}$ of distilled water and $5 \mathrm{~mL}$ of post-frac treatments were added. The reactors were capped and heated to $100^{\circ} \mathrm{C}$ for 150 minutes, and an aliquot of $2 \mathrm{~mL}$ was taken every 30 minutes. Using the DNS method, the post-frac treatment's capacity to degrade the filter cake was measured and visual tests were recorded.

\section{Dynamic Activity of Post-Frac Treatment at Reservoir Temperature}

Post-frac treatments were used in dynamic activity tests in a certified Berea, which had an absolute permeability to water of $0.120 \mathrm{pm}^{2}$. The procedure used was based on the work conducted by Park et al. (2001).
The Berea was saturated using $\mathrm{KCl} 1 \% \mathrm{w} / \mathrm{v}$ brine by displacement and the operating conditions of the test were: $\mathrm{T}$ : $110^{\circ} \mathrm{C}$, back pressure $0.69 \mathrm{MPa}$, overburden pressure: $6.9 \mathrm{MPa}$, and flow rate $1 \mathrm{~mL} / \mathrm{min}$.

Absolute permeability was determined in the Production Direction (PD) using standard $\mathrm{KCl} 1 \%$ w/v brine. Post-frac treatments were displaced through the Berea at a rate of 2 Porous Volumes (PV) per hour until $6 \mathrm{PV}$ in Injection Direction (ID) was reached. The permeability was measured again using $\mathrm{KCl} 1 \%$ $\mathrm{w} / \mathrm{v}$ brine to verify whether the treatment caused any damage in the Berea.

Moreover, effluents from each post-frac treatment displacement were collected at every PV and were used for testing their capacity for polymeric degradation and their chemical activity retention.

\section{Polymer Degraded in a Porous Media by Post-Frac Treatments Corefloods}

Coreflood tests were performed in Bereas which simulated fractured rocks. The fractures were created in high permeability Bereas with a $0.120 \mathrm{pm}^{2}$ absolute water permeability and $0.23 \mathrm{~cm}$ width, and packed with ceramic proppant 20/40. The Bereas were saturated using $\mathrm{KCl} 1 \% \mathrm{w} / \mathrm{v}$ brine by displacement, with the following operating conditions: $\mathrm{T}: 110^{\circ} \mathrm{C}$, back pressure $2.76 \mathrm{MPa}$, overburden pressure: $20.68 \mathrm{MPa}$, and flow rate $1 \mathrm{~mL} / \mathrm{min}$.

Initial permeability was determined using standard $\mathrm{KCl} 1 \% \mathrm{w} / \mathrm{v}$ brine (PD). Then, $2 \mathrm{PV}$ of cross-linked fracturing fluid were displaced in ID, without exceeding $3.45 \mathrm{MPa}$ of differential pressure. A closure time of 2.5 hours was provided to allow the breaking of the fracturing fluid. Permeability was measured again using $\mathrm{KCl} 1 \% \mathrm{w} / \mathrm{v}$ brine (PD). Effluents were collected every $\mathrm{PV}$ for polymer quantification.

When stability in the differential pressure was achieved, 2 PV of post-frac treatment were displaced in ID. According to polymer degradation tests in linear gel, different closure times were defined for the different post-frac treatments to safeguard the reaction times. Permeability was measured in PD using $\mathrm{KCl} 1 \% \mathrm{w} / \mathrm{v}$ brine, and effluents were collected every PV for polymer quantification. The results of permeability's return before-and-after application of post-frac treatments were analyzed. 
In addition, the polymeric quantification was prepared using the DNS method as follow: In glass test tubes, with a cap, $2 \mathrm{~mL}$ of the collected effluent samples were added, and $0.2 \mathrm{~mL}$ of hydrochloric acid $15 \% \mathrm{v} / \mathrm{v}$ were also added. The tubes were agitated and homogenized. Following, the test tubes were incubated at $95^{\circ} \mathrm{C}$ for 90 minutes to hydrolyze the polymer. Afterwards, the DNS method was implemented to measure the polymer degraded as glucose in the solution, and performing a mass balance was possible to quantify the polymer retained in the fractured Berea.

\section{RESULTS AND DISCUSSION}

\section{Post-Frac Treatments Compatibility with the Chichimene Oil and Rocks, Unit K-1}

Initially, compatibility tests were performed between $\mathrm{CH}-26$ oil and $\mathrm{KCl} 1 \% \mathrm{w} / \mathrm{v}$ brine. The commercial surfactant concentration was gradually increased up to $0.2 \% \mathrm{w} / \mathrm{v}$, when phase separation was obtained with defined interfaces. This formulation was used as basis fluid for preparing the post-frac treatments.

Figure 3 shows (from left to right), the results of compatibility tests between $\mathrm{CH}-26$ oil and ammonium persulfate, perborate and sodium hypochlorite, hydrochloric acid, enzyme treatment, and organic treatments I and II, respectively (50/50 and 80/20). In addition, fresh treatments, treatments after reaction with the polymer, and treatments with $\mathrm{Fe}^{+2}$ are showed from top to bottom.

Compatibility tests between $\mathrm{CH}-26$ oil and sodium hypochlorite did not produce phase separation in the ratio $80 / 20$. It was necessary to increase the surfactant concentration to $0.6 \% \mathrm{v} / \mathrm{v}$.

Although phase separation of some CH-26 vs. postfrac treatments after reaction with the polymer did not produce defined interfaces due to the presence of residual polymer in the treatments, all the results were satisfactory or acceptable.

Figure 4 shows the results of the normalized chemical analysis of the ions in the filtered supernatant obtained in the compatibility tests between post-frac treatments and crushed rock samples. Figures $4 \mathrm{a}$ and $4 \mathrm{~b}$ show results using Libertad Norte- 1 sands and Apiay-11 sands, respectively. The results showed similar trends for both of the rock samples used.

Hydrochloric acid and organic treatments I and II showed the highest reactivity with minerals present in the two sample sands. The persulfate treatment showed moderate reactivity, compared to other treatments. On the other hand, the enzymatic treatment showed low reactivity with the two rock samples. This was due to the fact that this enzyme is highly specific for the polymer. In this case, the high calcium concentration is caused by the calcium added commercially to the enzyme to activate it.

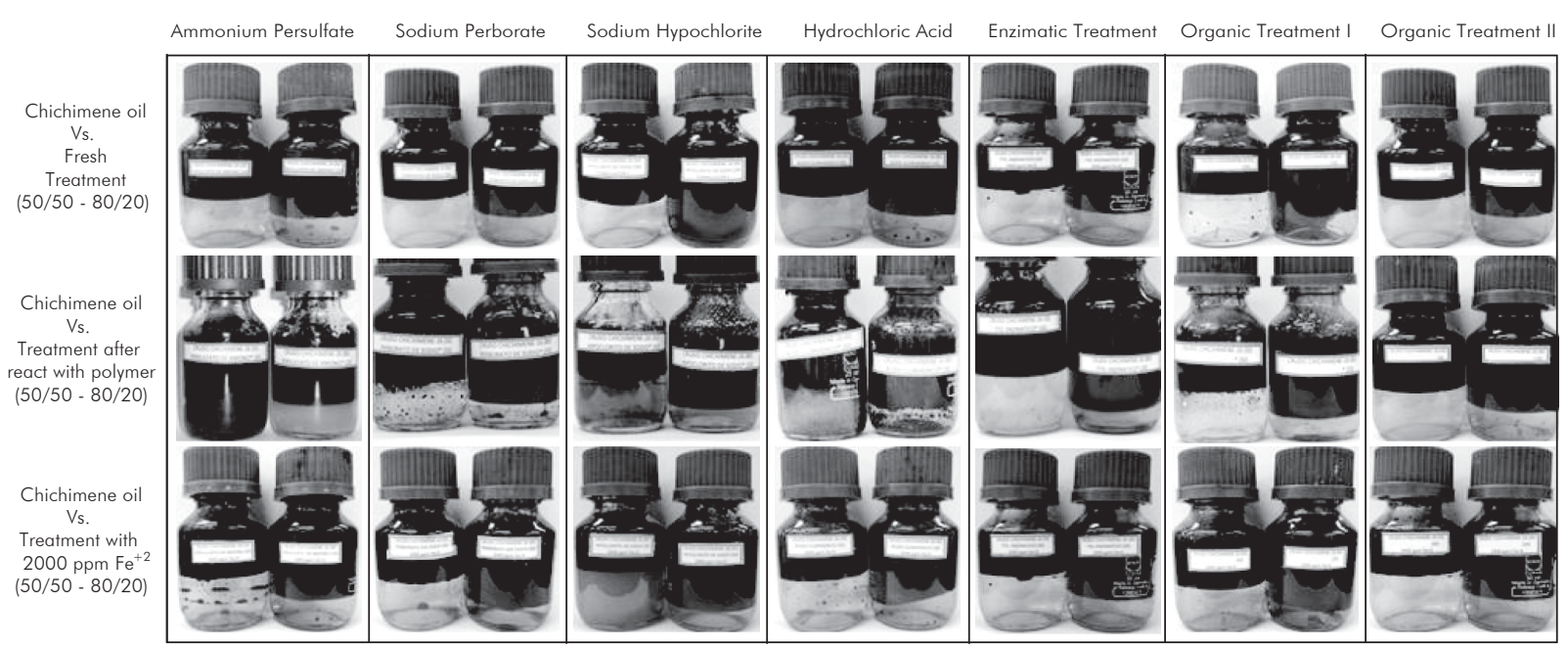

Figure 3. $\mathrm{CH}-26$ oil vs. fresh post-frac treatments, treatments after react with the polymer and post-frac treatments with $\mathrm{Fe}^{+2}$ compabilities, 50/50 and 80/20 relations. 


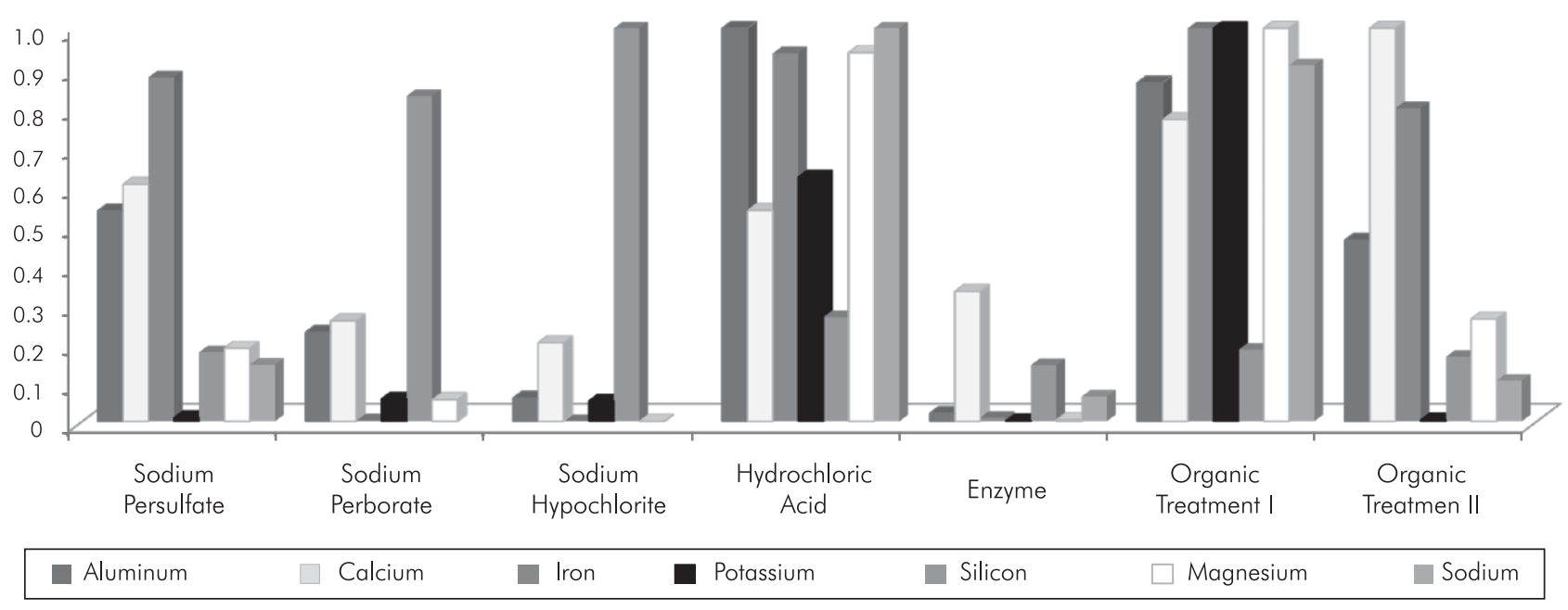

(a)

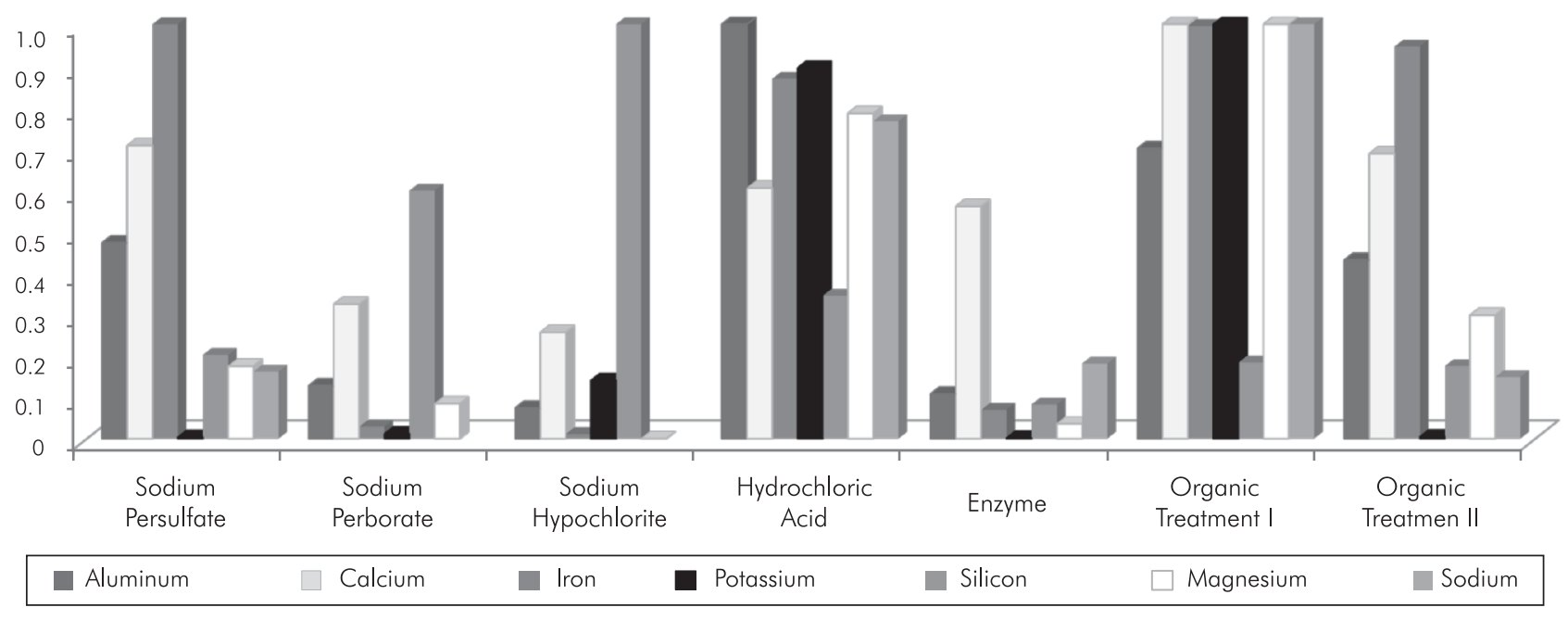

(b)

Figure 4. Normalized chemical analysis of the filtered fluid form compatibility test between a) Libertad Norte-1 (Depth: 3337 m) and b) Apiay-11 (Depth: 3216 m) sands versus the post-frac treatments.

Furthermore, the remaining rock samples were weighed to determine weight lost. According to the results showed in Table 3, the hydrochloric treatment was dismissed because it caused a sand dissolution greater than $1 \% \mathrm{w}$ for both of the samples tested, implying possible formation damage by fines migration.

Conversely, although the organic treatment I dissolved some extent of the rock, it does not exceed the limit of dissolution established. However, exposure time should be considered to avoid formation damage by fines migration (McDowell, Hunt \& Sitar, 1986).

Results showed sensitivity to acids on the rock samples tested. Hence, the use of acid treatments, in the Unit K-1 in the Chichimene oil-field, should be considered very carefully to avoid induced fines migration (McDowell et al., 1986). 
Table 3. Rock samples dissolution in post-frac treatments.

\begin{tabular}{|c|c|c|c|c|c|c|c|c|}
\hline & $\begin{array}{l}\text { Post-frac } \\
\text { Treatment }\end{array}$ & $\begin{array}{c}\text { Ammonium } \\
\text { Persulfate }\end{array}$ & $\begin{array}{l}\text { Sodium } \\
\text { Perborate }\end{array}$ & $\begin{array}{l}\text { Sodium } \\
\text { Hypochlorite }\end{array}$ & $\begin{array}{c}\text { Hypochloric } \\
\text { Acid }\end{array}$ & Enzyme & $\begin{array}{c}\text { Ammonium } \\
\text { Persulfate }\end{array}$ & $\begin{array}{c}\text { Ammonium } \\
\text { Persulfate }\end{array}$ \\
\hline \multirow{2}{*}{$\begin{array}{c}\text { Sand } \\
\text { Dissolution } \\
(\% w)\end{array}$} & Apiay-11 Sands & 0.22 & 0.11 & 0.20 & 1.18 & 0.05 & 0.66 & 0.23 \\
\hline & $\begin{array}{l}\text { Libertad } \\
\text { Norte - } 1 \text { Sands }\end{array}$ & 0.16 & 0.18 & 0.19 & 1.24 & 0.04 & 0.54 & 0.17 \\
\hline
\end{tabular}

\section{Polymer Degraded in the Fracturing Fluid Linear Gel}

The results of polymer degraded as linear gel, are showed in Figure 5. Figure 5a shows the results obtained using fresh treatments, and Figure $5 \mathrm{~b}$ shows those obtained using the effluents from the post-frac treatments dynamic activity tests. Linear gel without treatments was used as baseline to compare results.

At a reaction time less than 4 hours, the enzymatic treatment proved the most effective to degrade the polymer, followed by sodium hypochlorite and ammonium persulfate treatments (which are oxidant breakers). The enzymatic treatment retained about $60 \%$ of its catalytic activity after its contact with the Berea Sandstone in the dynamic activity test, whereas hypochlorite treatment retained about $80 \%$, in comparison to the persulfate which lost its chemical activity almost completely.

The Oxidant-breakers' ability for breaking the polymer is limited by their stoichiometric reaction (Armstrong et al., 2010) and their incapacity to regenerate their chemical activity. Furthermore, the high temperature induced a rapid decomposition of the breakers into highly reactive free radicals (Kidd, 2001). Moreover, enzymes have the ability to regenerate their catalytic activity, catalyzing the hydrolysis of the polymer continuously. However, the fact that the enzyme -after four hours of reaction did not continue catalyzing the hydrolysis of the polymerindicates that it was denaturized due to high temperature (Armstrong et al., 2010).

Contrariwise, the organic treatments behaviors were similar in both experiments for all the times tested. Considering that organic acids are weak acids, with low capacity to dissociate in aqueous solution, this would explain the organic treatments' low capacity to degrade the polymer during the first hours of reaction. According to the Van't Hoff equation, the high temperature effect stimulates the dissociation ability, and therefore their capacity to degrade the polymer (Van't Hoff, 1884; Van't Hoff, 1898; Laldler \& King, 1983).

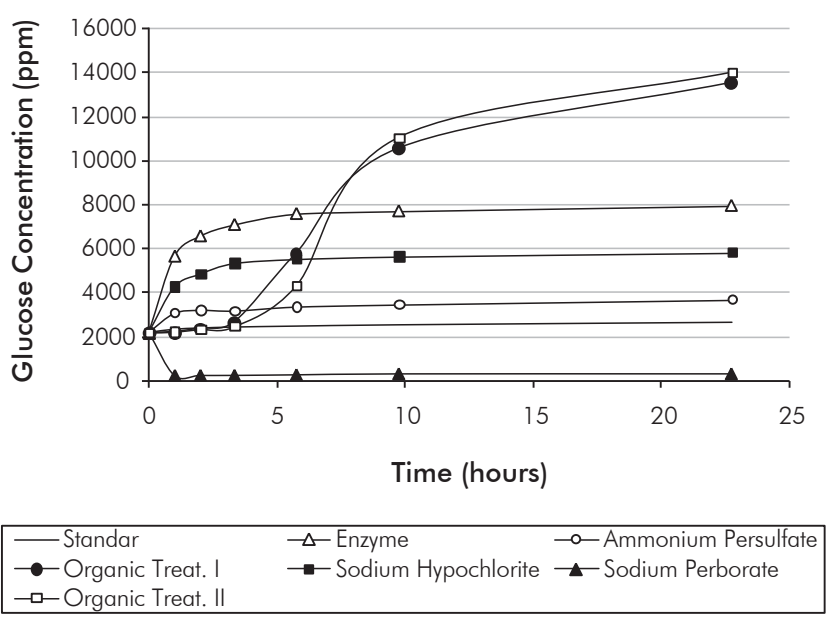

(a)
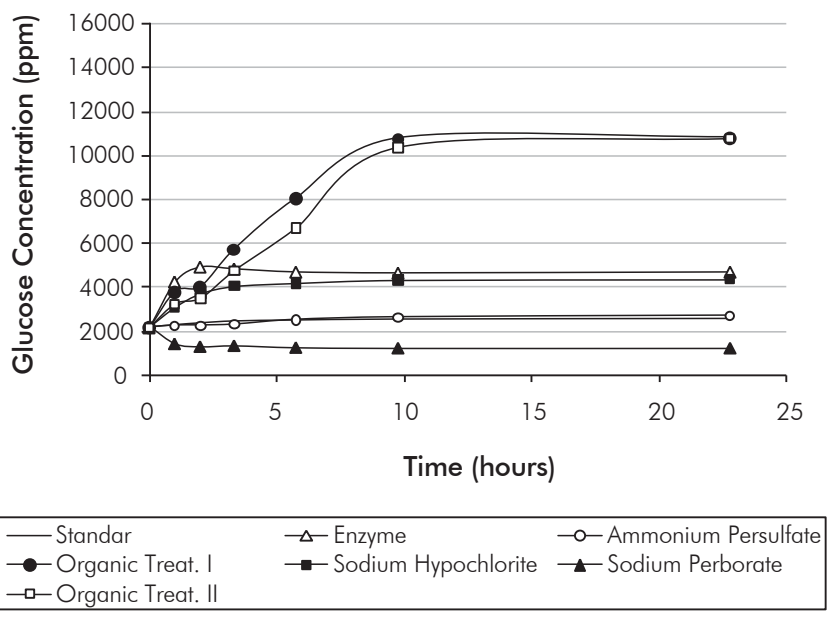

(b)

Figure 5. Fracturing fluid polymer degraded using a) fresh treatments and b) the effluents from the post-frac treatments dynamic activity tests. 
However, in instances where the reaction time was greater than five hours, these treatments degraded the largest amount of polymer. Both treatments retained $80 \%$ of chemical activity to degrade the polymer, after the dynamic activity tests at reservoir temperature.

Contrary to the other post-frac treatments, sodium perborate did not degrade the polymer. The salt is hydrolyzed in water to produce boric acid -a Lewis acid-, as it is not ionized to form $H^{+}$ions. In fact, it is attacked by the water hydroxyl group $\mathrm{OH}^{-}$to form the monoborate ion $\mathrm{B}(\mathrm{OH})_{4}^{-}$as shown in the Reaction 1:

$$
\mathrm{B}(\mathrm{OH})_{3}+2 \mathrm{H}_{2} \mathrm{O} \rightleftarrows \mathrm{B}(\mathrm{OH})_{4}^{-}+\mathrm{H}_{3} \mathrm{O}^{+}
$$

The monoborate ion produces polymer cross-linking reactions; when present in excess, inter- and intramolecular polymer cross-linking reactions (syneresis) are produced, reducing the solution's viscosity without producing a degraded polymer (Harris \& Sabhapondit, 2009; Shah \& Watters, 1986; Shah, Harris \& Tan, 1988; Nimerick, Temple \& Card, 1997). As was evidenced by the result obtained with the DNS method, perborate uses as a breaker in fracturing fluids that must be re-evaluated to reduce polymeric damage in the fractured area. Since perborate does not promote polymeric degradation, this treatment was not considered in the following evaluations. The post-frac treatments displacement through the Berea, during the dynamic activity test, did not produce any critical variations in permeability.

\section{Filter Cake}

The filter cake production was not reproducible under any conditions (Figure 6a). In order to obtain reproducible results in the cake degraded tests, it was decided to split the cake formed in each disk to perform degradation tests with the post-frac treatments. Results are shown in Figures $6 \mathrm{~b}$ and $6 \mathrm{c}$.

As it can be seen in Figure 6b, the enzymatic treatment produced response values were three times greater than the other treatments. However, it was observed that the treatment did not degrade the filter cake in a visual-sample inspection.

Enzymes catalyze polymeric hydrolysis by approaching reactions -meaning, by a reaction surface- and the polymer must be located in the active center of the

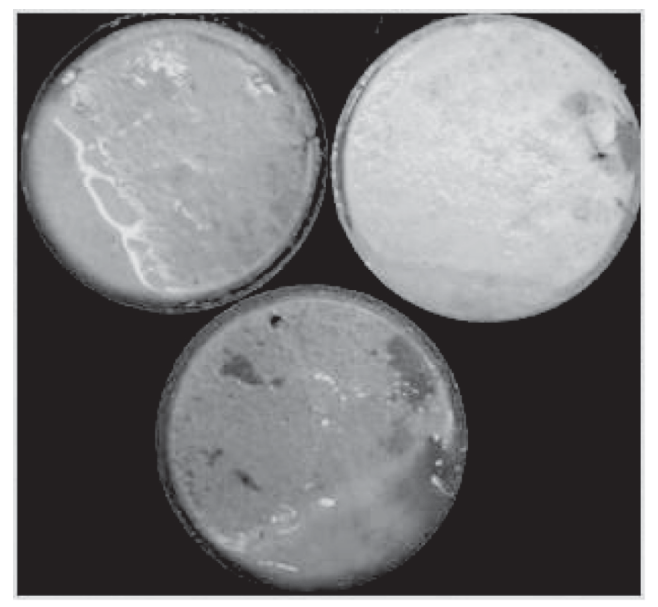

(a)

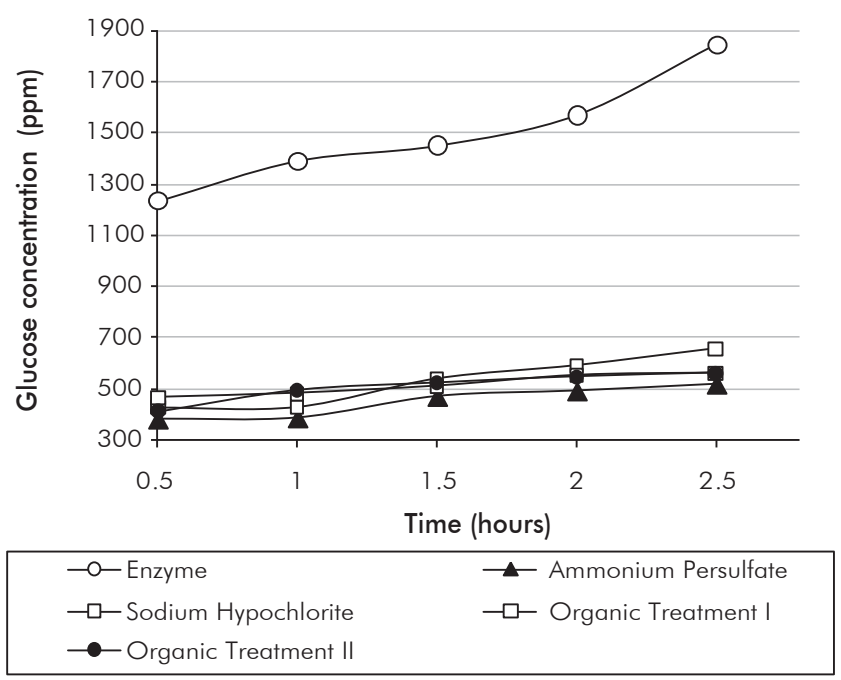

(b)

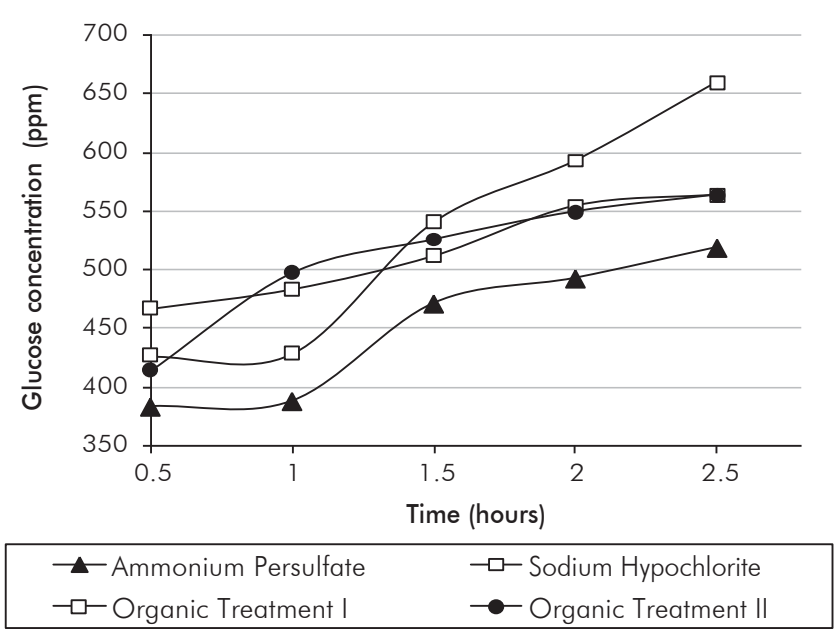

(c)

Figure 6. Polymeric degradation in the Filter cake. a) Differences in Filter Cake generated, b) Results of Filter Cake degradation using post-frac treatments and c) Zoom in on results of Filter Cake degradation. 
enzyme to perform the catalytic reaction. In the filter Cake, the polymer was concentrated in a mass free of water. For this reason, the enzyme could not degrade the polymeric mass. Then, the high DNS response obtained ought to be due to the enzyme degrading in large quantities, a small amount of polymeric suspension not belonging to the cake itself.

In comparison, the sodium hypochlorite treatment proved being the most effective treatment degrading the cake after 2.5 hours of reaction (see Figure 6c). Additionally, the organic treatments showed similar trends, degrading much of the cake when compared to the ammonium persulfate treatment. Because of its low performance, ammonium persulfate was not considered for the subsequent tests.

\section{Polymer Degraded in a Porous Media by Post-Frac Treatments Corefloods}

Figure 7 shows the porous media fractured and packed with ceramic proppant 20/40, as well as the fracturing fluid before-and-after two hours of reaction at $110^{\circ} \mathrm{C}$ used in the coreflooding tests.
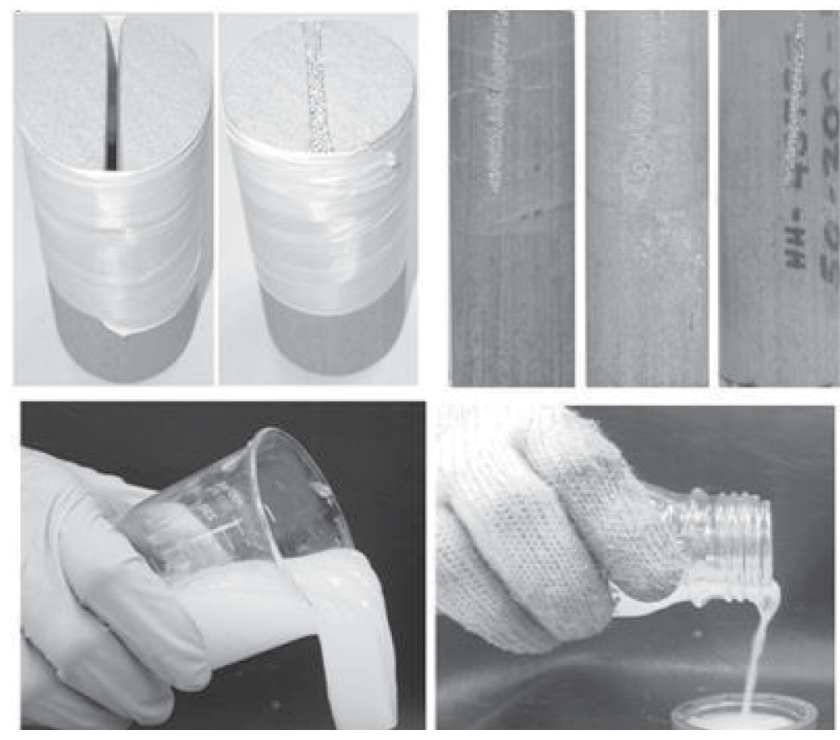

Figure 7. Coreflooding utilities: Sample Berea preparation and fracturing fluid used.

Under the testing conditions, the soaking times for the treatments were: 3 hours for sodium hypochlorite, 4 hours for organic treatment I due to its reactivity with the sand, 4 hours for enzymatic treatment, and 12 hours to organic treatment II. The post-frac treatments were applied twice in order to study the effects in polymer recovery and increase in permeability.

In the first instance, there was evidence of similar amounts of polymer that were retained in the three porous medium during the coreflooding tests -that is to say that similar amounts of polymer were recovered during the clean-up-. However, as shown in Table 4, different percentages of initial permeabilities were obtained. The main factor in decreasing permeability after injecting and displacing the fracture fluid is the way in which the polymer is retained in the porous system. Thus, small amounts of polymer can cause blockages greater than the amount that it physically occupies (Wang, Holditch \& McVay, 2008; Xiance \& Boyun, 2010) (see Figure 8).

Table 4. Coreflooding summary.

\begin{tabular}{|c|c|c|c|}
\hline \multirow{2}{*}{ Stage } & \multirow{2}{*}{$\begin{array}{l}\text { Polymeric } \\
\text { recovery } \\
\text { (\%w) }\end{array}$} & \multicolumn{2}{|c|}{ Permeability (K) } \\
\hline & & $\begin{array}{c}\% \text { of Initial } \\
\mathrm{K}\end{array}$ & $\mathrm{K}\left(\mathrm{pm} \mathrm{m}^{2}\right)$ \\
\hline \multicolumn{4}{|c|}{ Coreflooding 1} \\
\hline Clean up & 47 & 37 & 0.071 \\
\hline $\begin{array}{c}\text { Sodium hypochlorite } \\
1 \text { st time }\end{array}$ & 35 & 59 & 0.114 \\
\hline $\begin{array}{c}\text { Sodium hypochlorite } \\
\text { 2nd time }\end{array}$ & 8 & 89 & 0.172 \\
\hline \multicolumn{4}{|c|}{ Coreflooding 2} \\
\hline Clean up & 49 & 32 & 0.056 \\
\hline Enzyme 1st time & 9 & 29 & 0.052 \\
\hline Enzyme 2nd time & 2 & 20 & 0.036 \\
\hline Organic Treatment I & 25 & 51 & 0.089 \\
\hline \multicolumn{4}{|c|}{ Coreflooding 3} \\
\hline Clean up & 49 & 16 & 0.029 \\
\hline $\begin{array}{c}\text { Organic treatment II } \\
\text { lst time }\end{array}$ & 16 & 45 & 0.084 \\
\hline $\begin{array}{c}\text { Organic treatment II } \\
\text { 2nd time }\end{array}$ & 15 & 68 & 0.128 \\
\hline
\end{tabular}

The results of coreflooding tests of sodium hypochlorite treatment, enzymatic treatment \& organic treatment I and organic treatment II evaluations are shown on Figures $8 \mathrm{a}, 8 \mathrm{~b}$, and $8 \mathrm{c}$, respectively. 


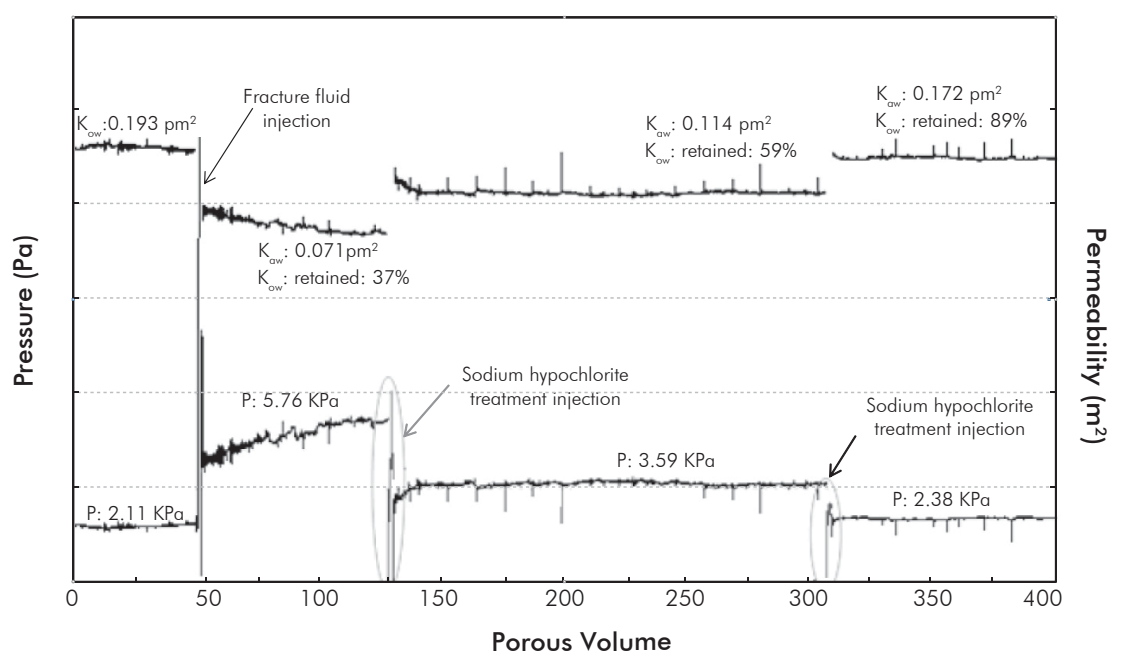

(a)

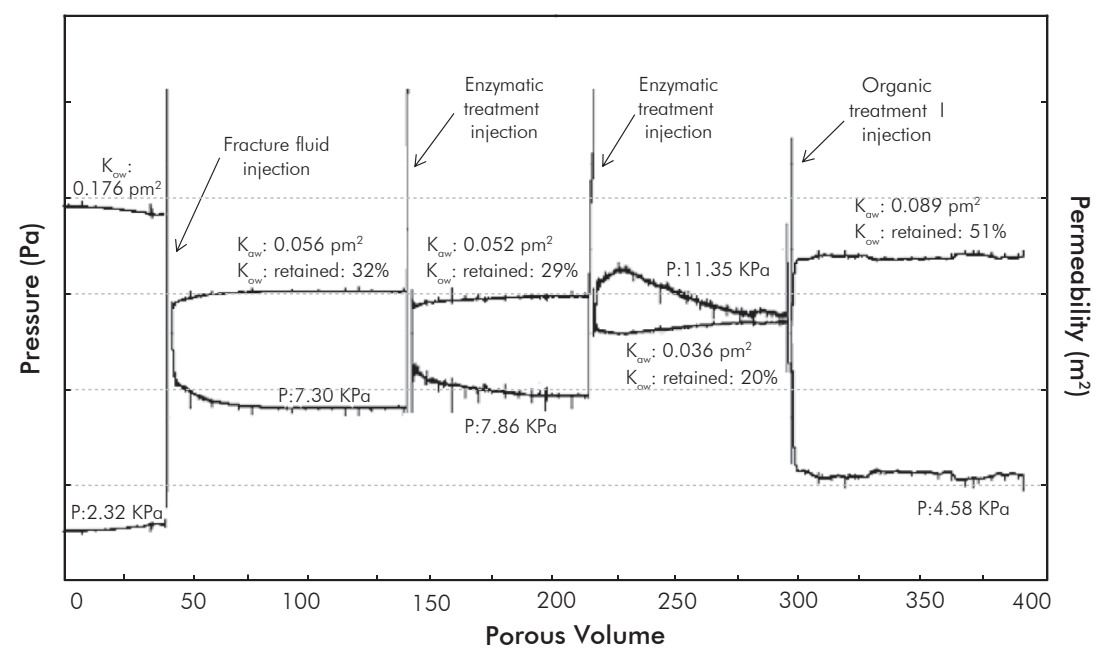

(b)

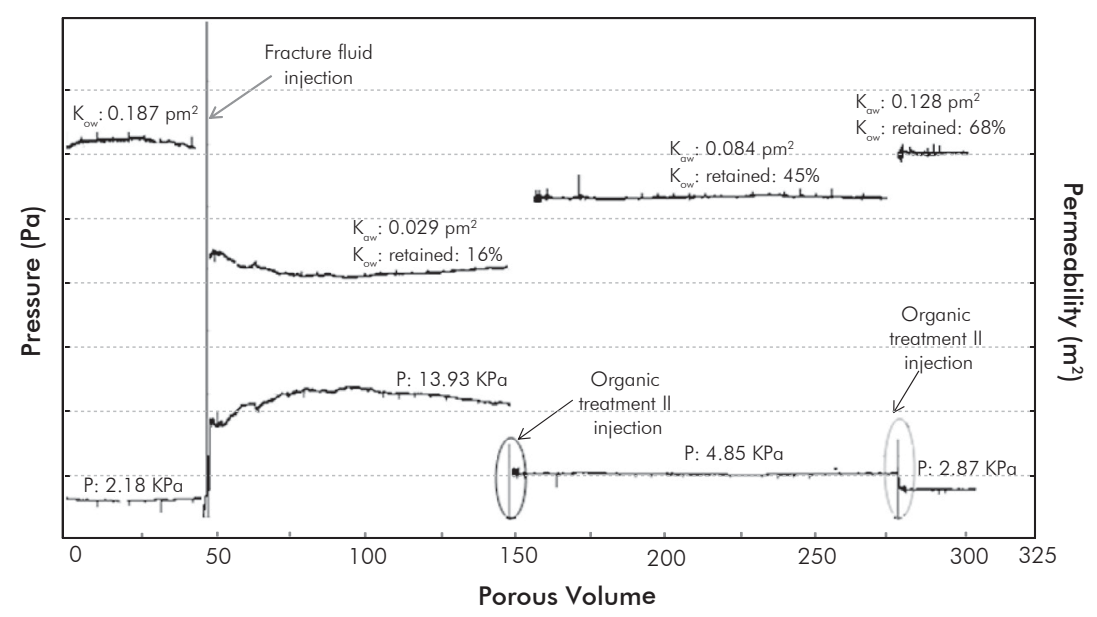

(c)

Figure 8. Permeability and differential pressure obtained with each post-frac treatment test. a) Sodium Hypochlorite Treatment, b) Enzymatic \& Organic Treatment I, c) Enzymatic \& Organic Treatment II. 
The sodium hypochlorite treatment, Figure 8a, which was applied twice, removed the most amount of retained polymer in the porous system. Following the second application, permeability increased up to $89 \%$ of its initial value.

On the other hand, the enzymatic treatment (Figure $8 b)$ did not remove the polymer, and caused a decrease in permeability. This particular treatment did not degrade the polymer retained in the pore system due to the polymer being mainly filter cake. Furthermore, an adverse effect in permeability was caused by polymer rearrangement into new pore spaces, increasing the damage caused by polymer retention.

The organic treatment I was applied in the same sample after the enzymatic treatment was applied (see Figure $8 \mathrm{~b}$ ), removing $25 \%$ of the polymer retained, and improving the percentage of initial permeability from 20 to $51 \%$.

The organic treatment II removed $16 \%$ and $15 \%$ of the polymer retained in both applications, respectively (Figure 8c). Although this treatment did not remove as much polymer as the sodium hypochlorite treatment, it produced the same increase in permeability.

As showed in Figure 9, effluents from organic treatment II showed between 4000 and $6000 \mathrm{ppm}$ of calcium for both coreflooding tests. The organic treatment II showed capability to degrade calcium carbonate and chelation. The calcium carbonate dissolution contributed to the formation of new flow channels, and permeability increase.

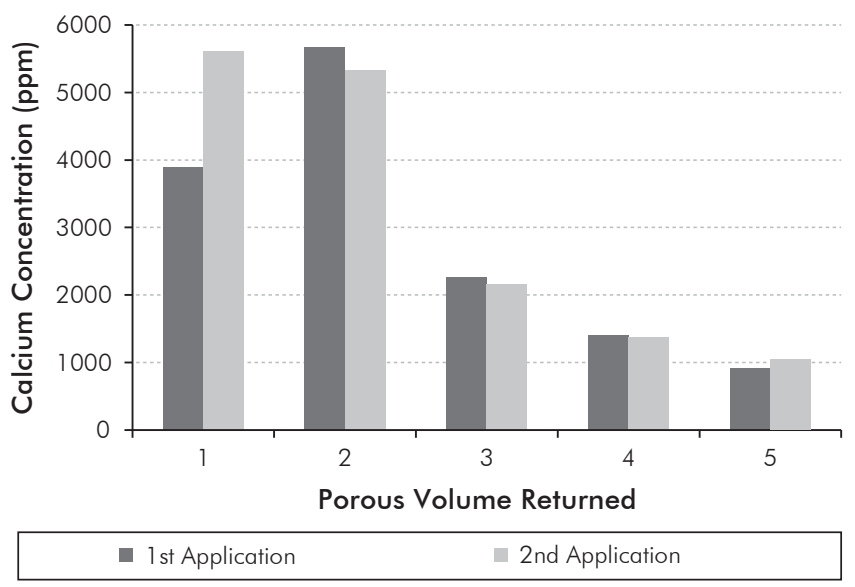

Figure 9. Calcium concentration in effluents of Organic Treatment II coreflood.

\section{CONCLUSIONS}

- The organics treatments I and II, both reacted in a similar way with the polymer, and proved effective at breaking the polymer retained in the porous system restoring up to 51 and $68 \%$ of the initial permeability respectively. The application of the former in a single step, for a span of $4 \mathrm{~h}$ of soaking time was due to its high reactivity with the rock. The Latter, organic treatment II, could also contribute to carbonates scale dissolution and chelation.

- Although the enzymatic treatment is not stable at high temperatures for a long time, the enzymatic treatment and organic treatments I \& II showed better linear gel degradation efficiency than other traditional breakers. Thus, these new treatments could be implemented as post-frac treatments to enhance post-fracturing fluid recovery and increase the productivity index.

- In comparison, the perborate breaker produces syneresis, causing more polymer retention and increasing damage into pore system. Whereas, the sodium hypochlorite treatment revealed to be very effective in breaking down the polymer retained in the porous system and restoring the initial permeability up to $89 \%$.

- The persulfate treatment attests to be the least effective treatment, as it degrades less of the polymer than the other treatments at same conditions. Furthermore, it is not stable at high temperatures.

- All the breakers tested diminished their efficiency as temperature decreased.

- The DNS method is a direct method for measuring the degraded polymer. This is a fast and simple method, and could be implemented easily in laboratory conditions for quality control.

- Finally, the usage of standard solutions to calibrate the methods, the appropriate data record and the statistical analysis of results are paramount to ensure the best results during the design of post-fracturing chemical treatments. 


\section{ACKNOWLEDGEMENTS}

The authors would like to express their gratitude to Ecopetrol S.A. -Instituto Colombiano del Petróleo (ICP) for providing their consent to the publication of these results as well as for their generous support throughout the extent of the project. Special thanks to the Universidad Industrial de Santander (UIS).

\section{REFERENCES}

Armstrong, C. D., Stevens, R. F., Le, H., Stephenson, C. \& $\mathrm{Qu}, \mathrm{Q}$. (2010). The next generation of regenerative catalytic breakers for use in alkaline and high-temperature fracturing fluids. SPE International Symposium and Exhibition on Formation Damage Control, Lafayette, USA. SPE 127936.

Asadi, M. \& Woodroof, R. (2006). Comparative study of flowback analysis using polymer concentrations and fracturing fluid tracer methods: A field study. SPE International Oil and Gas Conference and Exhibition in China, Beijing, China. SPE 101614.

Brannon, H. D. \& Tjon-Joe-Pin, R. (1996). Characterization of breaker efficiency based upon size distribution of polymeric fragments resulting from degradation of crosslinked fracturing fluids. SPE Annual Technical Conference and Exhibition, Denver, USA. SPE 36496.

Brannon, H. D. \& Tjon-Joe-Pin, R. (1995). Application of damage removal treatment results in multi-fold well productivity improvement: A case study. SPE Western Regional Meeting, Bakersfield, USA. SPE 29677.

Carrascal, F. A., Pachón, Z. P. \& Molina, D. V. (2013). Development and application of a new methodology to quantify breakers efficiency of water-based fracturing fluids. Fuentes: El Reventón Energético, 11(2), 65-69.

DeVine, C., Tjon-Joe-Pin, R. \& Rickards, A. (1999). Relationship between polymeric fragment damage and damage removal and the original rock and proppant pack permeability. SPE Mid-Continent Operations Symposium, Oklahoma, USA. SPE 52128.

Duxenneuner, M. R., Fischer, P., Windhab, E. \& CooperWhite, J. (2008). Extensional properties of hydroxipropyl ether guar gum solutions. Biomacromolecules, 9(11), 2989-2996.
Harris, P. C. \& Sabhapondit A. (2009). Chemistry applied to fracture stimulation of petroleum wells. SPE Middle East Oil and Gas Show and Conference, Bahrain. SPE 120029-MS.

Hoeman, K., Klasner, S. \& Karcher, A. (2011). Method for identification and analysis of polysaccharide-based, hydraulic fracture flowback fluid. SPE International Symposium on Oilfield Chemistry, The Woodlands, USA. SPE 141146.

Kidd, D. (2001). Fracturing. In situ technology. Boca Raton: CRC Press LLC.

Laldler, K. J. \& King, C. M. (1983). The development of transition-state theory. J. Phys. Chem., 87: 2657-2664.

McDowell-Boyer, L. M., Hunt, J. R. \& Sitar, N. (1986). Particle transport through porous media, Water Resour. Res., 22(13), 1901-1921.

Miller, G. L. (1959). Use of dinitrosalicylic acid reagent for determination of reducing sugar. Anal. Chem., 31(3), 426-428.

Nimerick, K. H., Temple, H. L. \& Card, R. J. (1997). New $\mathrm{pH}$-buffered low polymer borate crosslinked fluids for hydraulic fracturing. SPE Journal, 2(2), 150-156.

Park, E. I., Bennett, S., Powell, R., Procyk, A. \& Griffin, D. (2001). Application of a concentrated oxidizing breaker preflush in high-permeability frac-pac treatments. SPE European Formation Damage Conference, The Hague, Netherlands. SPE 68918.

Shah, S. N., Harris, P. C. \& Tan, H. C. (1988). Rheological characterization of borate crosslinked fracturing fluids employing a simulated field procedure. SPE Production Technology Symposium, New México, USA. SPE 18589.

Shah, S. N. \& Watters, L. T. (1986). Time and shear effects on rheological properties of crosslinked fluids- and evaluation method. SPE Production Engineering, 1(1), 55-61.

Van't Hoff, J. H. (1884). Etudes de dynamiquechimique. Amsterdam: Frederik Muller \& Co.

Van't Hoff, J. H. (1898). Lectures on theorical and physical chemistry, Part 1, Chemical dynamics. London: Translated by Lehfeldt A. R. Edward Arnold.

Wang, J. Y., Holditch, S. A. \& McVay, D. A. (2008). Simulation of gel damage on fracture fluid cleanup and long-term recovery in tigh gas reservoirs. Eastern Regional/AAPG 
Eastern Section Joint Metting, Pittsburg, Pensylvania. SPE 117444.

Wang, J., Holditch, S. \& McVay, D. (2012). Effect on gel damage on fractures fluid cleanup and long term recovery in tight gas reservoirs. J. Nat. Gas Sci. Eng., 9: 108-118.

Wientjes, R., Duits, M., Bakker, J., Jongschaap, R. \& Mellema, J. (2001). Linear viscoelastic behavior of enzymatically modified guar gum solution: Structure, relaxations and gel formation. Macromolecules, 34(17), 6014-6023.

Wientjes, R., Duits, M., Jongschaap, R. \& Mellema, J. (2000). Linear rheology of guar gum solutions. Macromolecules, 33(26), 9594-9605.

Xiance, Y. \& Boyun, G. (2010). How significant is the formation damage in multi-fractured horizontal wells?. International Symposium and Exhibition on Formation Damage Control, Lafayette, USA. SPE 125905.

\section{AUTHORS}

Fabián-Alfredo Carrascal-Delgado

Affiliation: Universidad Industrial de Santander

Chemist, Universidad Industrial de Santander

Chemical Engineer, Universidad Industrial de Santander M. Sc. in Chemistry, Universidad Industrial de Santander e-mail: fabian.carrascal@correo.uis.edu.co

\section{Zarith del Pilar Pachón-Contreras}

Affiliation: Ecopetrol S.A. -Instituto Colombiano del Petróleo (ICP) Chemist, Universidad Industrial de Santander

M. Sc. in Chemistry, Universidad Industrial de Santander e-mail: zarith.pachon@ecopetrol.com.co

\section{Daniel-Ricardo Molina-Velasco}

Affiliation: Universidad Industrial de Santander Chemist, Universidad Industrial de Santander $\mathrm{Ph}$. D. in Chemistry, Universidad Industrial de Santander e-mail: dmolina@uis.edu.co 
